\title{
宷
}

\section{SURGIMENTO E DISPERSÃO \\ DO BUDISMO NO MUNDO}

-ALEXANDRE M. A. DINIZ'

\section{RESUMO}

O PRESENTE ARTIGO TEM COMO FOCO ESTUdAR A DIFUSÃO DO BUdISMO PELO MUNDO, IDENTIFICANDO SUA ABRANGÊNCIA E A DISTRIBUIÇÃO HETEROGÊNEA DOS SEUS SEGUIDORES. APRESENTA, COM ÊNFASE NOS ASPECTOS CULTURAIS, A EVOLUÇÃO hISTÓRICA NORTEAdA PELA GÊNESE, PRINCíPIOS, PROCESSOS DESTA DIFUSÃO - MUITAS DAS VEZES POR ESFORÇOS INDIVIDUAIS ISOLADOS - E CISMAS ANALISADOS SOB 0 OLHAR DA GEOGRAFIA DA RELIGIÃO ASPIRANDO À CONSTRUÇÃO DE UMA ANÁLISE GEOGRÁFICA DO BUDISMO. ALÉM DISSO, 0 ARTIGO EM TELA NO QUE TANGE 0 PROCESSO DIFUSOR REVELA QUE, PELO CARÁtER PACÍFICO DE COEXISTÊNCIA CARACTERÍSTICO DE SUA DOUTRINA, INCORPOROU PRÁtICAS ORIUNDAS DE OUTRAS RELIGIÕES - CAUSA PRINCIPAL DA EXISTÊNCIA DE DIVERSAS SEITAS E SUBGRUPOS NO SEIO BUDISTA.

PALAVRAS-CHAVE: DIFUSÃO, BUDISMO E TOLERÂNCIA RELIGIOSA.

INTRODUÇÃO

- Budismo é uma família de religiões e filosofias, sendo difícil afirmar quais de suas partes integrantes é original ou sofreu menos interferências. O Budismo representa, ainda, uma tradição metafísica da qual emana uma sabedoria aplicável a vários instantes da existência. A figura histórica de Siddhattha Gautama, também conhecido como o Buda, não deixou registros escritos de suas ideias, sendo seus ensinamentos formalmente codificados pelo menos quatro séculos após a sua morte. Tais ensinamentos revestem-se de caráter psicológico, filosófico e moral, sendo o Buda, costumeiramente, retratado como um mestre, um pensador, um sábio, um verdadeiro cientista (Silva e Homenko, 1978).
O Budismo apresenta uma série de peculiaridades em relação a outras religiões. Ao contrário do Hinduísmo e do Judaísmo, por exemplo, o Budismo tem origem num fundador, Siddhattha Gautama, o Buda. Por outro lado, ao contrário do Cristianismo e do Islã, esse fundador não representou uma encarnação divina ou um mensageiro divino, mas, ao contrário, foi um ser humano que expôs uma disciplina mental, desenvolvida e posta em prática com êxito por ele próprio. Outro aspecto importante em relação ao Budismo é o fato de ser uma religião não teísta, uma vez que rechaça a existência de um Deus ou Criador supremo, em que pese reconhecer a existência de seres não-humanos, como espíritos e divindades, tendo esses apenas posição periférica em relação à doutrina (Wijayaratna, 2002). 
A doutrina budista faz um apelo ao livre exame, à livre experiência do indivíduo, distinguindo-se de grande número de outras doutrinas religiosas. Segundo o próprio Buda (Challaye, 1998:84):

Não acredites numa coisa simplesmente por ouvir dizer; não acredites sob a fé das tradições, pois elas são veneradas bá numerosas gerações... Não acredites em nada através unicamente da autoridade de teus mestres ou sacerdotes. Crê no que tu mesmo experimentares, provares e reconbereces como verdadeiro, que esteja de acordo com teu bem e o dos outros, e conforma tua conduta a isso.

Essa confiança na razão individual é tão claramente afirmada que o Budismo poderia parecer, à primeira vista, uma filosofia e não uma religião. Acerca dessa provocante questão, Dalai Lama (apud Revel e Ricard, 1997:30), responde com bom humor:

"Pobre Budismo! É rejeitado pelos religiosos, que o definem como uma filosofia ateia, uma ciência do espírito, e pelos filósofos, que o vinculam às religiões. Assim, ele não tem direito de cidadania em lugar nenbum. Mas, isso talvez seja uma vantagem, que permite ao Budismo lançar uma ponte entre religiões e filosofias"

Destaque-se, ainda, o fato de que, ao contrário de boa parte das grandes religiões, o Budismo não contempla revelações acerca do mundo, sua origem, sua existência e seu fim. O Buda nunca se preocupou com tais questões e recusava-se a respondê-las, acentuando a inutilidade de tais discussões em comparação com o objetivo da vida religiosa (Wijayaratna, 2002).

Desde o seu surgimento no norte da Índia, no século $\mathrm{V}$ a.C., o Budismo expandiu-se pelo mundo, incorporando, em cada nação que o abraçou, aspectos das religiões, cultos e seitas locais. Essa expansão se deu de tal sorte que o espaço búdico dos idos dos séculos d.C. se estendia "de Samarcanda e Bukhara até a Manchúria, do Ceilão ao Japão, do Afeganistão a Java" (Robert, 2002B:477). No entanto, nos locais onde foram perseguidos, em distintas épocas, não surgiram mártires budistas. Afinal, o ensino de Buda não autorizou ninguém a criar a ideia de mártir, porque correr-se-ia o risco de suscitar entre os seguidores do Budismo amargas recordações de uma dada derrota, bem como sentimentos de ódio para com os perseguidores (Wijayaratna, 2002).

Hoje o Budismo é uma religião universal, com milhões de adeptos em várias partes do mundo. Trata-se de uma das mais tradicionais e fascinantes religiões, tem uma rica história e, por que não dizer, uma geografia impressionante. $\mathrm{Na}$ lista das principais religiões do mundo, o Budismo encontra-se em posição intermediária em relação a sua data de fundação, com mais de 2500 anos de existência, ocorrendo posteriormente ao Judaísmo, Zoroastrismo e ao Hinduísmo, por exemplo, mas muito antes de importantíssimas religiões, como o Cristianismo e o Islamismo (Tabela 1). 
TABela 1 - MaIORES Religiões do MUNDO

\begin{tabular}{|c|c|c|c|}
\hline Religião & Fundação & Membros & \% da Pop.Mundial \\
\hline Cristianismo & 30 D.C & 2,039 milhões & $32 \%$ (queda) \\
\hline Islamismo & 622 D.C & 1,226 milhões & $19 \%$ (cresc.) \\
\hline Hinduísmo & 1,500 A.C & 828 milhões & 13\% (estável) \\
\hline $\begin{array}{l}\text { Sem religião (agnósticos, } \\
\text { secularistas, humanistas, etc.) }\end{array}$ & - & 775 milhões & $12 \%$ (queda) \\
\hline Tradicional Chinesa & 270 A.C & 390 milhões & $6 \%$ \\
\hline Budismo & 523 A.C & 364 milhões & 6\% (estável) \\
\hline $\begin{array}{l}\text { Religiões tribais, Shamanismo e } \\
\text { Animismo }\end{array}$ & Pré-história & 232 milhões & $4 \%$ \\
\hline Ateísmo & - & 150 milhões & $2 \%$ \\
\hline Novas Religiões & Várias & 103 milhões & $2 \%$ \\
\hline Sikismo & 1500 D.C. & 23.8 milhões & $<1 \%$ \\
\hline Judaísmo & 4.000 A.C. & 14.5 milhões & $<1 \%$ \\
\hline Espiritismo (Kardecismo) & 1857 D.C. & 12.6 milhões & $<1 \%$ \\
\hline Fé Baha'I & 1863 D.C. & 7.4 milhões & $<1 \%$ \\
\hline Confucionismo & 520 A.C. & 6.3 milhões & $<1 \%$ \\
\hline Jainismo & 570 A.C. & 4.3 milhões & $<1 \%$ \\
\hline Zoroastrismo & 600 a 6000 A.C. & 2.7 milhões & $<1 \%$ \\
\hline Shintoismo & 500 D.C. & 2.7 milhões & $<1 \%$ \\
\hline Taoísmo & 550 D.C & 2.7 milhões & $<1 \%$ \\
\hline Outras & Várias & 1.1 milhões & $<1 \%$ \\
\hline Wicca & 800 A.C. & 0.5 milhão & $<1 \%$ \\
\hline
\end{tabular}

FonTE: Religious Tolerance (2006)

Estimativas dão conta que o número de budistas no mundo esteja entre 230 e 500 milhões, sendo que a maioria delas aponta números que oscilam em torno de 350 milhões (Adherents, 2006). Isso torna o Budismo uma das mais expressivas religiões do mundo em termos de seguidores, congregando nada menos do que $6 \%$ da população mundial, ficando atrás apenas do Cristianismo (32\%), Islamismo (19\%), Hinduísmo (13\%), de um numeroso grupo de indivíduos que se diz sem religião (12\%), e da religião tradicional chinesa (6\%) (Religious Tolerance, 2006). No entanto, os budistas estão distribuídos heterogeneamente pelo mundo, uma vez que as maiores populações budistas encontram-se, em termos absolutos, na China, Japão, Tailândia e Vietnã (Tabela 2). Por outro lado, em termos relativos, as maiores populações budistas estão na Tailândia, Camboja e Mianmar, todos com mais de $80 \%$ de suas respectivas populações professando o Budismo.

Mas como o Budismo deixou de ser um movimento restrito ao Norte indiano, tornandose uma religião universal? Por que, ao mesmo tempo, o número de adeptos dessa fascinante religião encontra-se distribuído de maneira tão heterogênea pelo mundo? Como se deu o processo de difusão espacial da religião? $\mathrm{O}$ presente trabalho tem por objetivo responder a essas perguntas. Para tal, buscar-se-á identificar os aspectos centrais do Budismo, resgatando parte de sua evolução histórica, enfatizando suas origens, princípios, processos de difusão e cismas. 
TABela 2 - PopulaÇÕES BUdistaS

\begin{tabular}{lccc}
\hline $\begin{array}{c}\text { Países com maior número } \\
\text { de budistas }\end{array}$ & $\begin{array}{c}\mathrm{N}^{\circ} \text { de budistas em } \\
\text { milhões }\end{array}$ & $\begin{array}{c}\text { Países com maior } \\
\text { proporção de budistas }\end{array}$ & $\begin{array}{c}\text { Percentual de } \\
\text { budistas }\end{array}$ \\
\hline China & 102 & Tailândia & $95 \%$ \\
Japão & 89,6 & Camboja & $90 \%$ \\
Tailândia & 55,4 & Mianmar & $88 \%$ \\
Vietnam & 49,6 & Butão & $75 \%$ \\
Mianmar & 41,6 & Sri Lanka & $70 \%$ \\
Sri Lanka & 12,5 & Tibete & $65 \%$ \\
Coreia do Sul & 10,9 & Laos & $60 \%$ \\
Taiwan & 9,1 & Vietnam & $55 \%$ \\
Camboja & 9,1 & Japão & $50 \%$ \\
Índia & 7,0 & Macau & $45 \%$ \\
& & Taiwan & $43 \%$ \\
\hline
\end{tabular}

FonTE: RusSELL (1997)

Este trabalho foi inspirado no recente movimento de valorização da Geografia Cultural, capitaneado pelos geógrafos Roberto Lobato Corrêa, do Departamento de Geografia da Universidade Federal do Rio de Janeiro e Zeny Rosendahl, professora do Departamento de Geografia da Universidade do Estado do Rio de Janeiro. No âmbito das possibilidades de estudos conferidos pela Geografia Cultural destacam-se aqueles relacionados à Geografia das Religiões. Trata-se de uma subdisciplina relativamente recente, cujas origens remontam ao início do século XX. Neste aspecto destacaram-se, até os anos 1960, estudos que buscavam compreender a força da religião como modificadora da paisagem, a partir das perspectivas possibilistas da Escola Vidaliana de Geografia, bem como da Escola de Geografia Cultural Sauriana. A partir da década de 1960, foram valorizadas as relações recíprocas entre religião e ambiente, o simbolismo dos lugares sagrados e as práticas espaciais associadas ao sagrado (Rosendahl, 1997).

Procurando fomentar a escassa produção brasileira nessa área, Rosendahl (1996) suscita o desenvolvimento de quatro temas associados à Geografia das Religiões: centros de peregrinação; território e territorialidade das religiões; percepção e vivência do espaço sagrado; e difusão e área de abrangência da religião. O presente estudo filiase à última área temática, uma vez que se busca identificar as áreas de abrangência e o processo de difusão do Budismo pelo mundo. O presente texto inicia-se com um arrazoado acerca da vida do Buda; a organização, história e dispersão e as diversas denominações da religião também são enfocados. Ao final, busca-se identificar os principais aspectos subjacentes à Geografia do Budismo. 
A VIDA DE BUDA

Existem dois pontos de vista para a discussão da vida de Buda. O primeiro, objetivo e analítico, construído a partir de relatos e evidências históricas; o segundo, subjetivo e direto, aceitando-se Gautama como o Buda, o desperto, o iluminado, aquele que salvou a humanidade do sofrimento e da cadeia de reencarnações. Neste texto, adotar-se-á, na medida do possível, a abordagem objetiva, uma vez que sua biografia só foi escrita séculos após a sua morte e as fontes são um misto de história e lenda (Humphreys, 1990).

Gautama Buda, o fundador daquilo que chamamos Budismo, viveu no Nordeste da Índia no século VI a.C. O seu primeiro nome era Siddhattha e o nome de família Gautama. O epíteto "Buda", que significa em sânscrito "o desperto", "o iluminado", "aquele que se deu conta", ou, ainda, "aquele que assimilou a verdade", foilhe atribuído mais tarde, após ter, supostamente, atingido estágio espiritual superior, aos 35 anos de idade. Siddhattha Gautama também era chamado de Bhagava (o abençoado) por seus discípulos, mas também de Shakyamuni (o iluminado do clã Shakya), uma vez que nasceu no clã Shakya, que dominava a porção do território indiano postado na borda meridional nepalesa (Dhammananda, 1987; Revel e Ricard, 997; Bowker, 2000).

Siddhattha nasceu príncipe, no ano de 563 a.C., nas planícies de Lumbini, no sul do Nepal. Tendo levado uma vida pautada pelo luxo sob a proteção do seu pai, Suddhodana, raja do clan Shakya, Siddharta casou-se aos 16 anos com uma prima de nome Yasodhara, com quem teve um filho, Rahula. A luxuosa e confortável vida no claustro palaciano sofreria uma reviravolta, quando, tomando conhecimento das realidades do mundo, concluiu que a vida é sofrimento (Kharishnanda, 1988).

Buscando descobrir um modo de aliviar o sofrimento humano, Siddhattha renunciou à faustuosa vida que levava e deixou o palácio e a família aos 29 anos de idade, para tornar-se um asceta. Durante seis anos acompanhou os grandes mestres espirituais da época sem grandes resultados. Foi assim que compreendeu que a vida asceta não fazia sentido e escolheu o "caminho do meio", uma alternativa longe do fogo das paixões e dos tormentos da automortificação.

Reza a lenda que Siddhattha sentou-se sob uma figueira (Bodhi), entrando em profunda meditação, resoluto de que não abandonaria esta posição até que alcançasse seu objetivo. Foi assim que, aos trinta e cinco anos de idade, Siddhattha transformou-se de um mero buscador da verdade em Buda, o iluminado. Os seus primeiros seguidores foram os ascetas que o acompanhavam. Nas quase cinco décadas que seguiram, Buda deambulou pela planície gangética, ensinando o Dhamma a expressivo número de seguidores, fundando uma ordem de monges e monjas (Percheron, 1958; Dhammananda, 1987). Siddhattha Gautama viveu até os 80 anos, vindo a falecer no ano de 483 A.C., deixando milhares de seguidores.

O BUDISMO

O Buda nada escreveu, tendo seus ensinamentos sidos puramente verbais, ficando na memória de seus discípulos que os transmitiram oralmente por repetição e recitação nos mosteiros da Índia. Mais tarde surgiram diversos tratados que 
constituem o cânone sagrado dos livros budistas, intitulado Tipitaka (em páli²) ou Tripitaka (em sânscrito) (Silva e Homenko, 1978).

Alguns teóricos postulam que os ensinamentos do Buda não representaram uma ruptura do Bramanismo então praticado. Vários termos brâmanes foram empregados, mas com significados distintos. Ele aceita a existência do renascimento por muitas vidas; o Samsâra, que resulta em novas vidas dependendo do Karma, a lei moral de causa e efeito ${ }_{i}$ juntamente com a noção da unidade de todas as formas de vida, e o objetivo de autolibertação. Todas essas noções encontravamse presentes no Bramanismo praticado nos dias de Siddhattha Gautama (Kharishnanda, 1988). Estes, no entanto, foram incorporados com significados próprios.

O Buda introduziu uma série de inovações. Primeiramente, negou vigorosamente o valor do sistema sacrificial Hindu, aconselhando seus seguidores a laborar, com diligência, sua própria salvação. Desta forma, antigos rituais ganham nova roupagem, com o sacrifício de animais, por exemplo, transmudando-se em autoentrega ao serviço de outros. Neste contexto, o objetivo não é ser absorvido pelo Brahman, o absoluto, nem tampouco a união com Deus, mas o Nirvana, que significa a cessação do desejo e do apego (Bowker, 2000).

Outro aspecto que diferencia o Budismo do Bramanismo é a noção de que "nada existe de permanente, nem no mundo material, nem no mundo espiritual. Não há universo, substância, em alma-substância. Existem apenas estados condicionados pelos que os precedem - que se agrupam momentaneamente para formar um universo ilusório, um eu ilusório" (Challaye, 1998:85). Outra grande contribuição foi a noção de que nenhuma alma, ou atman, renasce, porque não existe permanência em coisa alguma. $\mathrm{O}$ que existe é apenas "a sequência de um momento de aparência que dá origem ao seguinte, de modo que a morte simplesmente representa uma nova forma de aparência, humana ou animal, no céu ou no inferno" (Bowker, 2000:55).

Mas, segundo Challaye (1998), a originalidade do Budismo está no fato da doutrina contrariar certas tradições do meio social do qual surgiu, tendo sido criada a partir da própria experiência de vida de seu idealizador. No seu processo de disseminação, o Buda converteu reis e humildes trabalhadores, desconsiderando as diferenças de casta, franqueando a todos o acesso à vida religiosa, fato que representaria uma profunda revolução moral. Assim como é indiferente às distinções de casta e de classe, o Budismo também é indiferente em relação às diferenças raciais e às nações. Portanto, o Budismo pode ser encarado como universalista, uma vez que aspira a conversão de todos os seres humanos (Challaye, 1998).

Ao longo de sua evolução, o Budismo esteve exposto a uma miríade de interpretações dos ensinamentos originais do Buda, que, por sua vez, deram origem a um sem número de escolas, identificadas posteriormente neste texto. A despeito desse aparente desconcerto, os budistas como um todo compartilham vários princípios básicos (Robert, 2002A).

Primeiramente, todos aceitam o Buda Sakyamuni como mestre e rejeitam a ideia de um ser supremo criador e gestor deste mundo, bem como renunciam a toda e qualquer forma de dogma. 
Uma consequência do ateísmo búdico é o fato dele comportar apenas o culto da recordação, não sendo, portanto, possível rogar a Buda, que não é deus. Além disso, tendo o Buda ingressado no Nirvana, nada mais pode fazer pelos fiéis, além de servir como exemplo e inspiração (Challaye, 1998). Humphreys (1990) vai além, afirmando que na ausência de dogmas e deuses com o poder de avançar ou deter o avanço dos homens em direção a sua própria iluminação, os sacramentos e os sacrifícios deixam de ter sentido no Budismo.

Outro importante princípio compartilhado por todos os budistas é a noção de que Siddhattha Gautama não foi o primeiro humano a atingir a iluminação. Budas antes dele existiram e outros Budas ainda existirão. Portanto, a iluminação constitui-se não apenas numa promessa, mas na esperança de todos os budistas (Humphreys, 1990; Robert, 2002A).

Todos os budistas também compartilham o livro sagrado - Tripitaka (em sânscrito) ou Titipaka (em páli), que significa $O$ Triplo Cesto de Flores (Challaye, 1998; Robert, 2002A). Tratam-se dos textos de referência do Budismo tradicional, supostamente transmitidos pelo próprio Buda. Compõem o Tripitaka textos sobre a doutrina (Sutra Pitaka), a disciplina monástica (Vinaya Pitaka), bem como aqueles de caráter filosófico e psicológico (Abhidharma Pitaka). Esses elementos constituem a base do cânone páli, referência de ortodoxia em toda a história do Budismo (Kharishnanda, 1988).

Todas as escolas abraçam igualmente as quatro Nobres Verdades. A primeira verdade é aquela sobre a dor (em sânscrito, duhkha; em páli, dukkha), segundo a qual toda existência é insatisfatória e cheia de sofrimento. A segunda verdade é aquela sobre a origem da dor (em sânscrito e páli, samudaya), segundo a qual a causa direta é o ato, o Karma, causado por sua vez pela sede, pela apetência insaciável, que pode ter por objeto o prazer, a existência ou a não - existência. Em outras palavras, o dukkha deriva do tanha, o desejo ou apego, que significa o esforço constante de encontrar algo permanente e estável num mundo transitório (Robert, 2002A).

Em relação à transitoriedade do mundo, cabe aqui um parênteses. Esta encontra-se vinculada ao eterno ciclo de renascimentos, série de existências (Samsara), aos quais todos os seres humanos estão sujeitos. Esses ciclos, por sua vez, são governados pelas leis do Karma. Segundo o Budismo, o renascimento é uma continuidade de ações (Karma) e de reações, que fornecem a energia para renascer uma e outra vez. Em outras palavras, renasce-se numa situação que é resultante das ações praticadas em existências anteriores (Wijayaratna, 2002).

A terceira verdade é aquela sobre a supressão ou cessação da dor (Nirodha ou Nirvana ${ }^{3}$ ), que se encontra associada à possibilidade de pôr termo ao ciclo dos nascimentos e das mortes. A quarta verdade é aquela sobre a via (sânscrito, pratidad; páli, patipada) que conduz à supressão da dor, sistematizada pelo Buda no Caminho Óctuplo (Robert, 2002A).

O Caminho Óctuplo, por sua vez, é composto de passos, que não necessitam ser seguidos em nenhuma ordem específica, cada um descrito como "correto", ou samma, quais sejam: compreensão correta $_{i}$ pensamento correto ${ }_{i}$ fala correta ${ }_{i}$ ação correta $_{i}$ existência correta ${ }_{i}$ esforço correto ${ }_{i}$ atenção 
correta; e concentração correta. A compreensão correta ganha destaque central, encerrando a compreensão vital da "ascensão condicionada" ou "origem dependente", tema determinante na compreensão do Budismo. Trata-se de uma cadeia de doze elos, que explica como todas as coisas estão ligadas, como o erro e o apego ao erro surgem e como, se a cadeia é desfeita, o Nirvana pode ser alcançado (Bowker, 2000).

A respeito da Cadeia de Doze Elos, também conhecida como Lei das Doze Causas, Buda ensina que todos os fenômenos deste mundo mudam de forma constante, aparecendo e desaparecendo, e que todas as mudanças baseiam-se em uma regra estabelecida. Ainda que todas as coisas mudem, esta regra permanece imutável. Essa lei é conhecida como Lei das Doze Causas porque a regra se divide em doze etapas. Em relação à vida humana, as doze etapas são: "ignorância (mumyó), ações (gyó), consciência (shiki), nome e forma (as funções mentais e a matéria: myó-shiki), as seis entradas (os cinco órgãos dos sentidos e a mente: rokunyú), contato (soku), sensação (ju), desejo (ai), adesão (shu), existência (u), nascimento (shó) e velhice e morte (ró-shi)" (Niwano, 1984:115).

Outro aspecto compartilhado por todas as escolas é a estreita e simbiótica relação entre monges (bhikkhu/bhikshu) em comunidade (Sangha) e os leigos. Desde os primórdios, os budistas organizaram-se em quatro grupos: os monges (bhikkhu), as monjas (bhikkunî), os fiéis leigos (apâsakâ) e as fiéis leigas (upâsikâ). O Buda verificou que a maioria dos seres humanos encontram-se apegados aos prazeres sensuais e que apenas um pequeno grupo aceita abandoná-los. Em virtude dessa diferença de mentalidades, os fundadores do Budismo não quiseram ignorar completamente os não-renunciantes e decidiram fazê-los participar no seu empreendimento religioso, para que o ensino do Buda fosse útil ao bem-estar de muitos (Wijayaratna, 2002). Dessa forma, a comunidade laica supre os monges materialmente, enquanto estes levam ensinamento espiritual e mérito aos leigos e seus ancestrais. Desta forma, a doutrina do Budismo assenta-se sobre três pilares, chamados as "Três Joias": O Mestre Buda, seus ensinamentos (Darma/Dhamma) e sua comunidade de discípulos (Sangha) (Dhammananda, 1987).

A moral budista, sintetizada por Challaye (1998), também é compartilhada, em linhas gerais, pelo conjunto de seguidores. Esta moral apresenta uma dualidade: a moral negativa, que prescreve o que não se deve fazer; e a moral positiva, que prescreve aquilo que é necessário ser feito. Segundo o autor, a moral negativa é a da retidão, compreendendo cinco preceitos básicos: não matar $_{i}{ }^{4}$ não furtar ${ }_{i}$ não tomar a mulher do próximo; não mentir; e não beber licor embriagador. Por outro lado, a moral positiva budista recomenda a resignação ao sofrimento individual, a meditação sobre os sofrimentos dos vivos, o esforço para participar, em imaginação, de suas dores e alegrias, a benevolência, a piedade, o perdão das ofensas e o sacrifício por outrem.

\section{A HISTÓRIA DO BUDISMO. Os PRIMEIROS CONCíLIOS}

Nas décadas que seguiram à morte de Siddhattha Gautama, o Budismo representou um fenômeno de pouca expressão, com poucas referências e registros históricos. Dignos de nota, no entanto, foram os dois primeiros concílios que 
organizaram os princípios gerais do Budismo. O primeiro concílio ocorreu logo após a morte do Buda, ainda no século $\mathrm{V}$ a.C., com o objetivo de registrar o cânone páli (Tipitaka/Tripitaka) (Kharishnanda, 1988).

O segundo concílio ocorreu em 383 a.C., motivado por crescentes conflitos entre escolas tradicionais e um grupo de monges que demandavam certo relaxamento das regras monásticas. Para as escolas tradicionais, Buda havia sido um ser humano que alcançou o estado de iluminação, sendo este passível de ser alcançado desde que os monges seguissem as regras monásticas estabelecidas no primeiro concílio. Para o grupo dissidente (Mahasamghikas), esta perspectiva era demasiado individualista e egoísta, motivando a adoção de regras monásticas menos rígidas, que estivessem acessíveis a um grupo mais amplo de pessoas. Essas idéias foram rejeitadas no segundo concílio, promovendo uma cisão entre os budistas. Nascia, assim, a dicotomia entre as escolas ortodoxa (Theravada) e heterodoxa (Mahayana), das quais surgiram as diversas seitas budistas contemporâneas (Humphreys, 1990).

Pouco se sabe acerca do Budismo nas décadas que seguiram a realização do segundo concílio. No entanto, a história do Budismo mudaria de maneira radical com a chegada ao trono indiano de Asoka Maurya, ${ }^{5}$ no ano de 270 a.C.. O Rei Asoka converteu-se ao Budismo após sucessivas campanhas expansionistas, que, a certa altura, o fizeram arrepender-se dos horrores provocados pelos conflitos por ele comandados. Asoka renunciou à violência, passando a propagar a religião budista entre seus súditos e nações vizinhas, tornando-se chefe de Estado e da "Igreja".
No plano interno, Asoka foi um rei benevolente, construindo stupas, ${ }^{6}$ templos, hospitais, poços artesianos, cuidando do bem-estar de seus comandados e os unindo no Dhamma, fazendo do Budismo a religião da Índia. À medida que a influência do Budismo se estendia na Índia, desapareciam a guerra, a pena de morte, as perseguições e as grandes caças mortíferas. Os brâmanes, porém, combatiam vigorosamente a heresia que arruinava seus privilégios, mas tiveram que suportar, durante vários séculos, a expansão do Budismo em solo indiano (Challeye, 1998).

Sob os auspícios de Asoka, o terceiro concílio foi realizado, por volta de 250 a.C., com o objetivo de reconciliar as diferentes escolas, purificar o movimento budista de facções oportunistas atraídas pelo patrocínio real e estabelecer as viagens de missionários para todo o mundo. No entanto, a escola Mahayana não faz qualquer menção deste concílio, fato que sugere que, em face da substantiva cisão entre os budistas, este tenha sido um concílio exclusivamente Theravada (Humphreys, 1990).

Com a morte de Asoka, seu império foi rapidamente dilapidado, à medida que os ensinamentos brâmanes voltavam a se expandir. Sendo o Budismo, desde o seu nascimento, tolerante em relação a outras religiões, ainda que fossem antitéticas a ele próprio, fez pouco para obstar a crescente influência brâmane. O Budismo indiano só voltaria a ter suporte oficial sob o comando do império Kushan (séc. II a.C. a séc. III d.C.), que dominaram o Noroeste da Índia. Dentre os reis Kushan, Kanishka (78-103 d.C.) abraçou o Budismo ardentemente, patrocinando a realização do quarto concílio budista. Esse concílio tinha como objetivo harmonizar as crescentes 
divergências entre as escolas, tendo obtido, na melhor das hipóteses, resultados parcialmente satisfatórios. O motivo deste sucesso parcial foi o nível de participação das escolas. Os Mahayanistas não fazem menção a este concílio, e mesmo os Theravadistas do Sri-Lanka, Tailândia e Mianmar o ignoraram (Humphreys, 1990).

Com o fim do Império Kushan, o Budismo floresceria na Índia durante a dinastia dos Guptas (séculos IV-VI d.C.). Vários centros do saber Mayahana seriam criados, como Nalanda no Nordeste da Índia, que se tornariam umas das universidades budistas mais importantes durante vários séculos. No entanto, a partir do século VII, o Budismo indiano entraria em decadência em virtude das invasões dos Hunos Brancos e do Islã (Wikipedia, 2006). Desta forma, o Budismo na Índia foi, paulatinamente, perdendo força. As duas principais escolas permaneciam igualmente representadas, porém, no ano 1000 da era Cristã, pouco do Budismo indiano permanecia, encontrando-se, como nos dias atuais, apenas em pontos isolados do país (Humphreys, 1990).

\section{A EXPANSÃO BUDISTA}

O rei Asoka teve papel determinante no expansionismo budista, constituindo-se em missionário ardente. Graças a ele, o Budismo deixou de ser uma religião restrita ao Nordeste da Índia, para se tornar uma religião mundial. De acordo com os pilares e as placas deixados por ele ("Éditos de Asoka"), missionários foram enviados a todas as partes da Índia e a vários reinos, como Síria, Egito, Macedônia, e reino Greco-Bactriano (norte do Afeganistão) (Humphreys, 1990; Wikipedia, 2006). A prova disso é uma famosa coletânea filosófica sob a forma de diálogos entre um sábio budista e o rei grego Menandro, ${ }^{7}$ que governava a Bactriana no século II a.C. (Revel e Ricard, 1997). Asoka também foi determinante na expansão budista a leste do subcontinente indiano, sobretudo no atual Mianmar. Graças a Asoka, o povo Mon converteu-se ao Budismo por volta de 200 a.C. Outra missão importante foi aquela enviada ao Sri Lanka, também no século II a.C, responsável pela conversão do rei Devanampiya Tissa e outros nobres (Kharishnanda, 1988; SilkRoad, 2006).

Mesmo com a morte de Asoka e o declínio do Budismo na Índia, as duas escolas prosseguiram a sua peregrinação, espalhando-se pelo mundo. Neste sentido, a antiga Rota da Seda cumpriu importantíssimo papel, uma vez que, além de transportar mercadores, mercadorias e migrantes, essa via internacional também foi utilizada na dispersão do Budismo. A Rota da Seda, termo cunhado pelo geógrafo alemão Ferdinand von Richthofen, constituía-se em importante rota de comércio que ligava o Oriente ao Ocidente, conectando Xi'na, na China, às cidades portuárias mediterrâneas de Antióquia e Tiro. Uma extensa rede de estradas conectava a Índia a vários pontos da Rota da Seda e a outras vias terrestres de comércio, ligando o subcontinente indiano ao atual Mianmar e ao Sudeste asiático. Rotas terrestres de comércio também prosseguiam no sentido leste, ligando Xi'an, na China, a península coreana. No entanto, em virtude das colossais distâncias, poucos eram os mercadores que atravessavam toda a extensão da rota. A grande maioria cobria apenas pequenas seções da estrada. As mercadorias, no entanto, percorriam grandes distâncias, passando 
por várias mãos até atingir o destino final. Apesar do nome, muitos eram os produtos transportados por esses caminhos: papel, peles e cerâmica, viajavam da China para o Oeste; por outro lado, marfim, vidro e especiarias viajavam no sentido contrário (Asia Society Museum, 2006).

Nesse contexto, a Ásia Central desempenhava papel fundamental na articulação entre os mundos chinês, indiano e persa. As diversas ramificações da rota da seda para ali convergiam, trazendo mercadorias e influências culturais diversas. Lendas dão conta que essa região esteve sob influência do Budismo desde o tempo do Buda, quando, supostamente, dois irmãos mercadores da Báctria, Tapassu e Bhallika travaram contato com Siddhattha Gautama, tornando-se seus discípulos. Quando regressaram à Báctria construíram templos dedicados ao Buda. Missionários budistas, também viajavam com as caravanas através da Rota da Seda no primeiro século da Era Cristã. Com eles a fé budista espalhou-se por vastas regiões, fazendo com que a religião se tornasse predominante na Ásia Central (Silk-Road, 2006).

A partir da Ásia Central, o Budismo chegou à China, por volta do século I d.C. A introdução oficial do Budismo no país data de 67 d.C., com a chegada dos monges Moton e Chufarlan. Em 1968, sob patrocínio imperial, eles estabeleceram o Templo do Cavalo Branco, nas cercanias da capital imperial Luoyang. O Budismo na China floresceu no início da dinastia Tang (618-907 d.C.), que foi marcada por sua receptividade em relação aos contatos com outros povos. Em função disso, foram registradas várias viagens de monges budistas chineses à Índia entre os séculos IV e XI d.C. No entanto, no fim da dinastia Tang, as influências externas passaram a ser evitadas, sendo que em 845 d.C. o imperador Wuzong proibiu todas as religiões "estrangeiras", com o objetivo de apoiar o Taoísmo. Ao longo do território, o imperador mandou confiscar os bens budistas e destruir templos e mosteiros (Asia Society Museum, 2006; Silk- Road, 2006).

Com o desenvolvimento do budismo na China, a religião chegou à Coreia em 372 d.C., quando embaixadores chineses visitaram o reino de Koguryo, levando consigo textos e esculturas. O Budismo viria a florescer na Coreia, em particular na sua forma Zen, a partir do século VII d.C.. A partir do século XIV d.C., com o início da dinastia confucionista Yi, o Budismo seria discriminado e praticamente erradicado, com exceção do movimento Zen (Asia Society Museum, 2006; Silk-Road, 2006).

O Japão tomou contato com o Budismo no século VII d.C., quando monges coreanos viajaram até às ilhas levando consigo escrituras e obras de arte. No século seguinte, o Japão adotaria o Budismo como religião oficial. O fato de estar situado no fim da Rota da Seda faria com que o Japão preservasse muitos aspectos do Budismo numa época em que este começava a desaparecer na Índia, Ásia Central e China (Asia Society Museum, 2006; Silk- Road, 2006).

A partir dos impulsos culturais que ainda emanavam do subcontinente indiano, o império marítimo Srivijaya, centrado na ilha de Sumatra, Indonésia, adotou o Budismo no século VI d.C. nas suas formas Mahayana e Vajrayana. Outro importante episódio da expansão budista deu-se nos séculos IX e XIII, quando o império Khmer, de religião budista Mahayana e hindu dominou a maior 
parte da península do Sudeste asiático. Sob o domínio Khmer, centenas de templos budistas foram construídos no Camboja e na Tailândia. Angkor foi o centro deste desenvolvimento, com um complexo de templos e organização urbana capaz de sustentar um milhão de habitantes.

No entanto, em função da perda de pujança do Budismo Mahayana na Índia do século XI, este também entrou em declínio no Sudeste asiático, sendo substituído, posteriormente, pelo Budismo Theravada, difundido a partir do Sri Lanka. Isso se deu em virtude das invasões islâmicas, que comprometeram as rotas comerciais continentais comandadas pela Índia, fazendo com que se desenvolvessem novas rotas marítimas entre o Oriente Médio e a China, que passaram a ser articuladas pelo Sri Lanka. Consequentemente, o Budismo Theravada, dominante naquele país, acabaria por se difundir pela Ásia (Wikipedia, 2006).

O rei Anawrahta, fundador do império birmanês, adotou o Budismo Theravada como religião oficial. Este fato geraria a construção de milhares de templos budistas na capital, Pagan, entre os séculos XI e XIII d.C.. O poder dos Birmaneses decaiu com a ascensão dos Thai e com a tomada da capital pelos Mongóis em 1287; apesar disso, o Budismo Theravada continua a ser a principal religião em Myanmar até hoje. O expansionismo Theravada prosseguiu, sendo posteriormente adotado pelo recém-formado reino tailandês de Sukhothai, por volta de 1260 d.C.. Durante o período Ayutthaya (séculos XIVXVIII d.C.) o Budismo seria reforçado como religião, tornando-se parte integrante da sociedade tailandesa. Ainda no Sudeste asiático, a tradição
Theravada continuou a sua expansão, alcançando Laos e Camboja no século XIII d.C.. No entanto, a partir do século XIV d.C., nas regiões costeiras e nas ilhas do Sudeste asiático cresceu a influência do Islã, sobretudo na Malásia, Indonésia e Filipinas (Wikipedia, 2006).

O Budismo foi introduzido tardiamente no Tibet. Desde o tempo do primeiro rei tibetano, Nyatri Tsenpo, a religião predominante no Tibet era o Bön. No entanto, durante o reinado de Lha Totori Nyentsen, ocorreram os primeiros contatos com o budismo. Seu quinto sucessor foi o rei Srongbtsansgam-po (617-698 d.C.), quem colaborou com o estabelecimento do budismo no império. Deve-se ressaltar que em virtude da posição geográfica do Tibete, situado entre a Índia e a China, seria normal que recebesse influências dessas duas civilizações desde o início de sua história. Portanto, as primeiras influências budistas tiveram dupla origem, não só em virtude da posição geográfica do Tibete, mas também graças às procedências das esposas de Srong-btsansgam-po: uma chinesa e a outra indiana. Desta forma, cada uma delas estabeleceu na capital real o culto búdico tal como era praticado em suas respectivas pátrias. Essa dupla transmissão não tardou a redundar numa confrontação, mas ao longo da história sabe-se que a tradição indiana se sobrepôs à chinesa, tendo o Budismo tibetano se desenvolvido sob forte influência tântrica (Robert, 2002B).

Um dos sucessores de Srong-btsansgam-po, Trisong Detsen (790-858 d.C.), convidou vários mestres Danashila de Singala, Kamalashila da China, Shantarakshita (Khenpo Bodhisattva) de Zahor, Vimalamitra de Kashmir e o Padmasambhava de Uddiyana. O rei patrocinou a tradução de 
textos budistas para o tibetano e, em 779 d.C., fundou o primeiro monastério tibetano, Samye (Revel e Ricard, 1997; Dharmanet, 2006). Por muitos séculos, o Tibet permaneceu isolado e desenvolveu uma forma única de Budismo, incorporando as filosofias e o monasticismo do Mahayana, os métodos tântricos do Vajrayana e as crenças nativas da religião Bön, com se verá mais adiante.

Apesar dos contatos com o Ocidente serem muito antigos, o Budismo começaria a despertar maior interesse entre os ocidentais apenas na segunda metade do século XX. Com a crescente desilusão suscitada pelos recorrentes fracassos de projetos políticos alternativos, como o Marxismo, por exemplo, o Budismo passou a inspirar vários intelectuais. Neste sentido, a doutrina depurada e, consequentemente, suscetível de ser aceita pelo espírito crítico e pelo racionalismo Ocidental, a ele acrescentando uma dimensão moral e espiritual, foram determinantes na crescente adoção do Budismo entre os intelectuais ocidentais. Dessa forma, já nos anos 1970, a busca pela realização pessoal de inspiração budista substituiu, em boa medida, a utopia de projetos políticos reestruturadores, que visavam introduzir mudanças radicais nas sociedades (Revel e Ricard, 1997; Wikipedia, 2006).

Entretanto, o fator determinante para a popularização do Budismo no Ocidente foi, sem sombra de dúvidas, deflagrado pela invasão e a anexação do Tibete pela China, respectivamente em 1950 e 1951. Esses movimentos foram acompanhados pela perseguição e massacre de budistas, além da destruição de bibliotecas e de cerca de seis mil mosteiros. Esses acontecimentos chamaram a atenção do Ocidente para a religião, causando compaixão em relação à causa tibetana. Em virtude desses acontecimentos, em 1959 o Dalai-Lama e mais de cem mil tibetanos deixaram seu país buscando exílio na Índia e em outras partes. Do exílio o Dalai-Lama iniciou uma pacífica luta pela restituição dos direitos dos tibetanos, que lhe rendeu o Prêmio Nobel da Paz, fato que ajudou a popularizar o Budismo no Ocidente (Revel e Ricard, 1997).

Deve-se destacar que, à medida que o Budismo penetrou diferentes países e culturas, a doutrina adotou ou foi ineficaz ao combater ideias e crenças locais, incorporando às práticas budistas originais princípios de outras religiões. Foi desta forma que o culto de espíritos da natureza, presentes na Tailândia, Sri Lanka e Mianmar, foram, paulatinamente, incorporados ao Budismo ali professado. Da mesma maneira, os credos confucionista, taoísta e shintoísta modificaram as práticas budistas na China e Japão. No Tibet, a religião original Bön corrompeu o Budismo Tibetano, que, por sua vez, já se encontrava imiscuído às práticas tântricas hindus (Humphreys, 1990). A partir dessas interseções, o Budismo assumiu diversas formas, sendo possível identificar um sem - número de escolas, seitas e subgrupos budistas.

No Brasil, a proporção de budistas ainda é diminuta (Tabela 3). O último censo contabilizou poucas centenas de milhares de budistas, colocando o Budismo na $11^{\mathrm{a}}$ colocação no rol das denominações religiosas praticadas no país. A chegada do Budismo ao Brasil está proximamente vinculada à imigração japonesa, iniciada em 1908. Esta foi originada pela simultânea necessidade de 
mão-de-obra no Brasil e a superpopulação e crise agrícola no Japão, tendo esta atingido seu ápice nas décadas de 1920 e 1930. No entanto, esses movimentos foram intensificados a partir de 1924, quando os EUA proibiram definitivamente a imigração japonesa, deslocando boa parte do fluxo de imigrantes japoneses para o Brasil. Essa situação fez com que, aproximadamente, 75\% dos 190.000 imigrantes que deixaram o Japão antes da Segunda Guerra (entre 1925 e 1935), aportassem no Brasil. A maioria dos imigrantes se fixou primordialmente no interior do Estado de São Paulo e no Norte do Paraná, tendo como ocupação principal a agricultura (Shoji, 2002).

\section{TABELA 3 - BUdismo No BRASIL}

\begin{tabular}{clcc}
\hline Ordem & Religião & Adeptos & $\%$ \\
\hline 1 & Católica apostólica romana & 124.980 .132 & 73,57 \\
2 & Evangélicas & 26.184 .941 & 15,41 \\
3 & Sem religião & 12.492 .403 & 7,35 \\
4 & Espírita & 2.262 .401 & 1,33 \\
5 & Testemunhas de Jeová & 1.104 .886 & 0,65 \\
6 & Católica apostólica brasileira & 500.582 & 0,29 \\
7 & Umbanda & 397.431 & 0,23 \\
8 & Sem declaração & 383.953 & 0,23 \\
9 & Não determinadas & 357.648 & 0,21 \\
10 & Outras cristãs & 235.532 & 0,14 \\
11 & Budismo & 214.873 & 0,13 \\
12 & Igreja de Jesus Cristo dos santos dos últimos dias & 199.645 & 0,12 \\
13 & Novas religiões orientais & 151.080 & 0,09 \\
14 & Candomblé & 127.582 & 0,08 \\
15 & Judaísmo & 86.825 & 0,05 \\
16 & Tradições esotéricas & 58.445 & 0,03 \\
17 & Católica ortodoxa & 38.060 & 0,02 \\
18 & Islamismo & 27.239 & 0,02 \\
19 & Espiritualista & 25.889 & 0,02 \\
20 & Tradições indígenas & 17.088 & 0,01 \\
21 & Outras religiosidades & 15.484 & 0,01 \\
22 & Outras religiões orientais & 7.832 & 0 \\
23 & Hinduísmo & 2.905 & 0 \\
& Total & 169.872 .856 & 100 \\
\hline
\end{tabular}

FONTE: IBGE 2000

Esses imigrantes pioneiros tiveram muitas dificuldades na sua adaptação ao Brasil, enfrentando um total desconhecimento da cultura brasileira e da língua portuguesa, além de preconceitos, condições precárias e de semi- escravidão nas fazendas. Em virtude desse processo de ocupação, boa parte dos budistas brasileiros encontram-se concentrados no Estado de São Paulo, no Norte do Paraná e no Sudoeste do Pará, todas áreas de forte colonização japonesa. 


\section{CONSIDERAÇÕES FINAIS}

Este breve relato de uma religião milenar trouxe à tona uma série de aspectos relevantes acerca do Budismo e seu processo de dispersão no mundo. Notou-se que o número de budistas se distribui de maneira irregular, com grande concentração de praticantes no Sul e Sudeste asiáticos, mas também no extremo Oriente. A construção dessa geografia foi comandada por uma série de elementos.

Primeiramente, em sua dispersão pelo mundo o Budismo contou com o auxílio de uma série de personalidades históricas, que, ao abraçar a religião, fizeram proselitismo, utilizando de seu poder e suas relações internacionais. Dessas personalidades devem-se destacar, em primeiro lugar, o rei indiano Asoka, fundamental na conversão de boa parte dos indianos, bem como em sua dispersão pelos reinos com os quais mantinha relações. Merecem destaque ainda os soberanos Mon do Mianmar, o rei Devanampiya Tissa do Sri Lanka, os membros da dinastia Tang chinesa, o rei birmanês Anawrahta, os Khmer no Camboja e Tailândia, e o rei tibetano Trisong Detsen, dentre outros. Nesse processo, antigas rotas de comércio foram fundamentais para que $\mathrm{o}$ Budismo se difundisse, chegando ao conhecimento de todas essas personalidades.

Nota-se, portanto, que o processo de dispersão deu-se, de acordo com os conceitos de Hagerstrand (1967), simultaneamente por contágio e de forma hierárquica. Graças à difusão por contágio, o Budismo espalhou-se paulatinamente, a partir do NE, incorporando territórios imediatamente vizinhos. Primeiramente, o centro e sul da Índia, entre os séculos V e II a.C. Com Asoka, o Budismo se espalhou para países lindeiros, Sri Lanka e Mianmar, ainda no século II a.C., tendo chegando à mesma época ao atual Afeganistão. Com o fim do patrocínio Asoka na Índia, desenvolvem-se dois outros núcleos irradiadores das influências budistas:

- um a partir da Ásia Central, de onde o Budismo Mahayana se irradiou para a China (séc. I d.C.); a partir daí, passou a influenciar o Vietnã (séc. II d. C.) e, posteriormente, a Coréia (séc. IV d. C.); a partir da Coreia, o Budismo chegou ao Japão (séc. VI d C.).

- a outra área de influência, desenvolve-se a partir do Sri-Lanka, de onde o Budismo Hinayana atingiu Mianmar (séc. V d.C.) e Indonésia (séc. VI d.C.) A partir do Mianmar o Budismo espalhou-se pela Tailândia e Camboja nos séculos posteriores.

Desenvolvimento tardio se deu no Tibet, que incorporou o Budismo Vajrayana, a partir de influências indianas no século VI d. C. Mas à medida que o Budismo incorporava essas novas áreas, ele se dispersava, ao mesmo tempo, de forma hierárquica, tanto espacial quanto socialmente. As novas ideias eram, primeiramente, assimiladas pelas capitais dos diversos impérios e reinados, pelos nobres. A partir daí, então, o Budismo se espalhava para os demais níveis das hierarquias urbanas dessas sociedades, até chegar ao mundo rural. À medida que esse espraiamento ocorria, as demais camadas da sociedade passavam a travar contato com a religião, passando a incorporá-la.

Outro elemento fundamental da dispersão do Budismo entre os séculos V a.C e VII d. C. foram as rotas de comércio, dentre as quais destacam-se 
a Rota da Seda. Afinal, além de estabelecer ligações relativamente seguras e estáveis entre Ocidente e Oriente, fazendo com que mercadorias e pessoas se locomovessem, as diversas ramificações dessa importante rota foram determinantes na comunicação da fé Budista. Curiosamente, à medida que novos centros budistas eram criados, com seus santuários, eles próprios passavam a intensificar os contatos entre os povos e o uso da Rota da Seda, desta feita, por motivos de outra natureza: a peregrinação religiosa.

O princípio de respeito, tolerância e gentileza para com todas as criaturas do mundo, central à fé budista, representou outro elemento crucial na dispersão budista pelo mundo. Nessa expansão pelo mundo, o Budismo nunca teve o caráter de um militarismo e em nenhum lado implicou a ideia de fazer desaparecer outras religiões. Tanto a mensagem como os meios utilizados para difundilo eram benevolentes, sendo que nenhum rei budista tentou propagar a sua religião pela força. Graças a esses princípios, à medida que o Budismo encontrava resistência ou era perseguido nos diversos contextos que ingressou, a doutrina adotou ou foi ineficaz ao combater ideias e crenças locais, incorporando às práticas budistas originais princípios de outras religiões.

\section{NOTAS}

1 PhD em Geografia. Professor Adjunto III - Programa de Pós-Graduação em Geografia - PUC Minas. dinizalexandre@terra.com.br

2 Páli é a lingua falada no Nordeste da Índia. Alguns acreditam ter sido ela a própria língua de Buda (Challaye, 1998)

3 O Nirvana respresenta a destruição do desejo, a destruição do ódio, a destruição do descaminho. Trata-se do fim da ignorância acerca das quatro verdades santas, ignorância que está na origem do apego à existência (Challaye, 1998)

4 O budista deve abster-se inclusive de matar animais.
5 Asoka foi o neto de Chandragupta, um oficial do exército que derrotou as forças gregas na Índia, após a morte de Alexandre, fundando, assim, o império indiano.

6 Antigas construções funerárias indianas, que guardam relíquias de reis e heróis (Bowker, 2000).

7 Essa interação pode ter influenciado a evolução Mahayana, uma vez que essa tradição apresenta perspectivas filosóficas e um tratamento do Buda como um deus, que muito lembra os deuses gregos. É também por esta altura que surgem as primeiras representações antropomórficas de Buda.

\section{REFERÊNCIAS BIBLIOGRÁFICAS}

Adherents. Disponível em http://www.adherents.com/ largecom/com_buddhist.html. Acessado em Novembro de 2006.

Asia Society Museum. Disponível em http://www.asiasocietym useum.com/buddhist_trade/traderoutes_overland.html). Acessado em 20 de Agosto de 2006

Bowker, John. Para Entender as Religiões. São Paulo: Ática. 2000.

Challaye, Félicien. As Grandes Religiões. São Paulo: Ibrasa. 1998.

Dhammananda, Sri. What Buddhists Believe. Kuala Lumpur: Buddhist Missionary Society. 1987.

Dharmanet. "Tibet, o Darma na Terra das Neves." Disponível em http://www.dharmanet.com.br/vajrayana/tibet.htm.

Acessado em Novembro de 2006

Hagerstrand, Torsten. "Innovation difusion as a spatial process." Chicago: University of Chicago Press, 1967.

Humphreys, Christmas. Buddhism: An Introduction and Guide. London: Penguin. 1990

Kharishnanda, Yogi. O Evangelho de Buda. São Paulo: Pensamento. 1988.

Niwano, Nikkyo. El Budismo Para El Hombre De Hoy. Barcelona:Edebé. 1984

Percheron, Maurice. Buda e o Budismo. Rio de Janeiro: Agir. 1958

Religious Tolerance. Disponível em http://

www.religioustolerance.org/worldrel.htm. Acessado em Outubro de 2006.

Revel, Jean-François e Ricard, Matthieu. O Monge e o Filósofo: o Budismo hoje. São Paulo: Mandarim. 1997.

Robert, Jean-Noël. "O Budismo: história e fundamentos." In Delumeau, Jean (Editor) As Grandes Religiões do Mundo.Presença:Barcarena - Portugal. 2002A. p. 429-442

Robert, Jean-Noël. O Grande Veículo na Índia e no Extremo Oriente. In Delumeau, Jean (Editor) As Grandes Religiões do Mundo. Presença: Barcarena - Portugal. 2002B. p. 477-505

Rosendahl, Zeny. Espaço e Religião: uma abordagem geográfica. Rio de Janeiro: EDUERJ. 1996.

"O Sagrado e o Espaço". In Castro, Iná

Elias. Gomes, Paulo César, e Corrêa, Roberto Lobato

(Editores). Explorações Geográficas. Rio de Janeiro: Bertrand Brasil. 1997. pp. 119-153.

Silk-Road. Disponível em http://www.silk-road.com/artl/ buddhism.shtml. Acessado em 20 de Agosto de 2006. 
Silva, Georges e Homenko, Rita. Budismo: psicologia do autoconhecimento. São Paulo: Editora Pensamento. 1978

Shoji, Rafael. "O Budismo Étnico na Religiosidade Nikkey no Brasil: Aspectos Históricos e Formas de Sobrevivência Socia"1. Revista de Estudos da Religião (REVER) número 4 - Ano 2 2002. Disponível em http://www.pucsp.br/rever/rv4_2002/ \#nota27, consultada em Novembro de 2006.
Wijayaratna, Môhan. "O Budismo nos Países do Theravada". In Delumeau, Jean (Editor) As Grandes Religiões do Mundo. Presença:Barcarena - Portugal. 2002. p. 443-476.

Wikipedia. History of Buddhism. Disponível em http:// en.wikipedia.org/wiki/History_of_Buddhism. Acessado em 20 de Agosto de 2006.

\section{ABSTRACT:}

THIS PAPER FOCUSES ON STUDYING THE SPREAD OF BUDDHISM THROUGHOUT THE WORLD, IDENTIFYING ITS EXTENT AND HETEROGENEOUS DISTRIBUTION OF HIS FOLLOWERS. PRESENTED, WITH EMPHASIS ON CULTURAL, HISTORICAL EVOLUTION GUIDED BY THE GENESIS, PRINCIPLES, PROCESSES THIS BROADCAST - OFTEN BY ISOLATED INDIVIDUAL EFFORTS - AND SCHISMS ANALYZED UNDER THE GAZE OF THE GEOGRAPHY OF RELIGION ASPIRING TO BUILD A GEOGRAPHICAL ANALYSIS OF BUDDHISM. IN ADDITION, THE ARTICLE REGARDING THE SCREEN PROTECTOR PROCESS REVEALS that, AT a PEACEFUL COEXISTENCE CHARACTERISTIC OF HIS DOCTRINE, INCORPORATED PRACTICES FrOM OTHER RELIGIONS - LEADING CAUSE OF EXISTENCE OF VARIOUS SECTS AND SUBGROUPS WITHIN BUDDHIST. KEYWORDS: DIFFUSION, BUDDHISM AND RELIGIOUS TOLERANCE. 
